ESJ Social Sciences

\title{
Effect of Green Manufacturing on Operational Performance of Manufacturing Firms in Mombasa County, Kenya
}

\author{
Eric Mutie Musau \\ Lecturer, Kingsford Rucha, PhD \\ Department of Management Science, School of Business, \\ University of Nairobi, Kenya
}

Doi:10.19044/esj.2021.v17n23p323

Submitted: 02 January 2021

Accepted: 22 June 2021

Published: 31 July 2021
Copyright 2021 Author(s)

Under Creative Commons BY-NC-ND

4.0 OPEN ACCESS

Cite As:

Musau E.M. \& Rucha K. (2021). Effect of Green Manufacturing on Operational Performance of Manufacturing Firms in Mombasa County, Kenya. European Scientific Journal, ESJ, 17(23), 323. https://doi.org/10.19044/esj.2021.v17n23p323

\begin{abstract}
This paper focuses on investigating the effect of green manufacturing on operational performance of manufacturing firms. The study adopted crosssectional survey design and data was collected across all the 61 manufacturing firms listed by KAM in 2019 through questionnaires. The study used Regression Model technique to analyze the quantitative data and validate the developed research model. Green manufacturing was found to have a positive effect on operational performance. Green product design and development, GSCM, and efficient processes had significant effect in enhancing operational performance while end-of-life product management was found to have insignificant relationship with operational performance.
\end{abstract}

Keywords: Green Manufacturing, Operational Management, Green Supply Chain Management, Efficient Processes, Green Product and Process Design, End-of-Life Product Management

\section{Introduction}

Due to globalization, firms have shifted to competing within supply chains by reducing cost of production, increasing flexibility, continuous quality improvement, and improvement on delivery (Famiyeh, Adaku, Gyampha, Darko \& Teye, 2018). Customers are changing their behavior by integrating environmental considerations into their lifestyles. As a result, 
purchasing decisions are made based on how well these products satisfy their needs and the effect they have on the natural environment. Industries are striving to enhance competitiveness within the supply chain by meeting the needs of their customers effectively (Rundh, 2013). The cost of energy is going up due to the world experiencing energy crises more frequently than ever ( $\mathrm{Li} \&$ Zhang, 2018), which has led to the necessity to reduce fuel consumption and use of renewable energy. Consumption of natural resources such as fuel, minerals, water, and food is on the rise every day with their availability shrinking. Therefore, it is paramount to conserve and manage resources (Bhattacharya, 2011) in order to enhance sustainability. Pollution levels are increasing every year with industrialization which leads to global warming and climatic change that negatively impacts the quality of life. There is a need for manufacturing firms to engage in sustainability in manufacturing by engaging in practices that use less natural resources and more renewable resources with little or no pollution (Zhang, 2018).

Kenya is an agricultural-based economy that is currently faced with teething problems in industrialization. Climatic change has also adversely affected the country's economy due to the increased frequency of droughts and famine, which has led to the straining of resources such as energy, water, and raw materials (UNICEF, 2017). As a way of curbing the effects of overreliance on agriculture, the country has set up a grand plan towards achieving industrialization by 2030. Manufacturing sector in Kenya has constantly contributed $11 \%$ to GDP for the last decade, which is an indication that it has remained flat (GoK, 2018). Kenya is an emerging economy that is striving to move away from agriculture-based economy to an industrial and middleincome economy. Thus, the manufacturing sector is required to grow its share in GDP contribution to achieve this objective (GoK, 2020).

According to KAM (2019), manufacturing industries carry out processing and value addition. Examples of manufacturing industries include building, mining and construction; chemical and allied; energy, electrical and electronics; leather and footwear; metal and allied; automotive; paper and board; pharmaceutical and medical equipment; plastics and rubber; textile and apparel; timber, wood and furniture; agriculture and fresh produce. An estimate of $9 \%$ of the total population of Kenya is in the coastal region and is growing at the rate of $2.9 \%$ per annum, which is relatively faster than the national growth of $2.7 \%$ per annum $(\mathrm{GoK}, 2019)$. This leads to an increase in the demand of products, and manufacturers are setting up industries in Mombasa to meet the demand. Natural resources are strained and industries face challenges of energy waste minimization, waste management, and compliance to regulations and policies. The ecosystem in the environment receives watershed discharge into the ocean which has an impact on biodiversity, productivity, and system functioning (NEMA, 2018). 
Manufacturing firms are under intense pressure to improve productivity and, at the same time, enhance environmental sustainability (Ahmad, 2015). Adopting green energy, green process, waste management, and minimization and reduction of pollution enables the manufacturing enterprises to enhance performance objectives such as reducing cost, corporate image, and reduced discharge of hazardous substances to the environment. Green manufacturing practices help to optimize resources, improve reliability, and reduce pollution (Famiyeh et al., 2018). They also ensure waste reduction which translates to better consumption of resources through the use of fewer raw materials and maximizing energy efficiently. This has an effect in cost reduction and quality improvement (Sivapirakasam, Mathew \& Surianayana, 2011).

Eshikumo (2017), Orji and Wei (2017), Fore and Mbohwa (2014), and Shrivastava and Shrivastava (2016) carried out studies on green manufacturing and operational performance on a single manufacturing firm. The studies acknowledged that there is a need to expand research to cater for a number of industries since the results may not be generalizable to all the industries. The initial capital required to purchase manufacturing equipment and machines is high, and most firms in developing countries are unable to upgrade the archaic methods used in production (Fore \& Mbohwa, 2014). Thus, the concern is reflected in the shift to green manufacturing and its ability to commensurate gains in the cost reduction.

\section{Research Objectives}

The broad objective of the study was to determine the effect of green manufacturing on operational performance of manufacturing firms. The specific objectives of the study were:

i. To establish the effect of green product and process design on operational performance of manufacturing firms.

ii. To examine the effect of efficient processes on operational performance of manufacturing firms.

iii. To establish the effect of GSCM on operational performance of manufacturing firms.

iv. To find out the effect of end-of-life product management on operational performance of manufacturing firms.

\section{Hypothesis}

The hypothesis of the study was:

$\boldsymbol{H}_{0}$ : Green manufacturing has no significant effect on operational performance of manufacturing firms in Mombasa County, Kenya.

$\boldsymbol{H}_{1}$ : Green manufacturing has significant effect on operational performance of manufacturing firms in Mombasa County, Kenya 


\section{Literature Review \\ Theoretical Foundations}

The study was anchored on Ecological Modernization Theory, Informational Theory, and Natural Resource Based View. Ecological Modernization Theory explains how pressures exerted by external institutions force manufacturing firms to adopt green manufacturing. The theory encompasses the evolving politics of pollution that refer to dynamism of regulations and their impact on environmental innovations. The theory also posits that manufacturers can gain operational performance improvements through innovations and enhancing their competitive advantage (Murphy \& Poist, 2003). Furthermore, manufacturers are adopting production systems that minimize the negative impacts of operations on the environment and natural resources (Kazancoglu et al., 2018; Bai \& Sarkis, 2018; Laosirihongthong \& Tan, 2013). Manufacturers are also striving to comply with regulations and policies set by governments and environmental institutions on carbon emission limits through the use of 6R strategy which involves redesign, reduce, remanufacture, recycle, reuse, and recover (Toptal, Ozlu \& Konur, 2014; Vachon \& Klassen, 2007; Ouardighi, Sim \& Kim, 2016). The formulation of international environmental regulations such as RoHS, WEEE, and ISO 14000 series coupled with increased environmental awareness of consumers have a significant impact on manufacturing firms and global trade (Chen, 2011; Terlaak, 2007).

Information theory explains how manufacturing firms should continuously and effectively communicate with their customers to enhance competitive advantage. Greater interactions through congruence, closeness, and collaboration between the manufacturers and other external institutions enhance sharing of information which reduces information asymmetry (Erlandsson \& Tillman, 2009). According to Sarkis (2012), firms may want to communicate their environmental performance to external stakeholders. However, this may be challenging due to inadequate information on the materials flowing through their supply chains. Implementation of ISO 14001 certification by manufacturers is a signal to the market that the firm is operating within recognized environmental management practice (González et al., 2008). Poorly performing units may adopt ISO 14001 certification which is a signal to the market that they are improving operations. Nevertheless, this may not be the case (Terlaak, 2007).

Natural Resource Based View (NRBV) theory articulates the interconnections among firm resources, capabilities, and competitive advantage. The firm should look for opportunities to gain competitive advantage from within rather than from the external environment. Tapping into resources that are valuable, scarce, inimitable, and non-substitutable maintains the competitive advantage of a firm (Alberto \& Sharma, 2003; Shi, 
Koh, Baldwin \& Gucchiella, 2012). NRBV focuses on two dimensions: the first dimension involves environmental pollution prevention. In this dimension, the firm designs, produces, and markets products that minimize negative effects to the environment throughout the product life cycle (Vachon $\&$ Klassen, 2007). The second dimension involves sustainable manufacturing, whereby the firm adopts strategies that minimize waste, utilize energy efficiently, and maximize clean technologies (Hart \& Gowell, 2011; Alberto \& Sharma, 2003). A firm's development in its resources and capabilities is demonstrated through improvements in quality and speed, reduction in cost, and increased flexibility. Therefore, building on these operational capabilities through green manufacturing supports the aspects of value, scarcity, distinctiveness, and non-substitutability which are features of NRBV that enhance the competitive advantage of the firm (Menguc \& Ozanne, 2005; Shi et al., 2012).

\section{Green Manufacturing}

Green Manufacturing is a 'new' manufacturing model that puts into consideration environmental sustainability and resource optimization throughout the product life cycle (Deif, 2011). The model aims at maximizing resource efficiency and minimizing negative impacts to the environment while reaping maximum economic and social benefits. Green manufacturing puts emphasis on abating the environmental effect by reducing, reusing, recycling, and remanufacturing which leads to source reduction, optimization of resource consumption, and enhancing use intensity (Fore \& Mbohwa, 2014; Shang, 2010). Green manufacturing dimensions also include green design and development, GSCM, investment recovery, and efficient processes (Shrivastava \& Shrivastava, 2017; Neto et al., 2009; Rehman \& Shrivastava, 2013). Green manufacturing involves recycling, waste reduction management, regulatory compliance, environmental protection, and pollution management (Rehman \& Shrivastava 2013; Orji \& Wei, 2016). According to Eltayeb (2019), green manufacturing has four dimensions: sustainable product design, sustainable process, sustainable supply chain management, and sustainable end-of-life management.

Green product design is enhanced through the use of design for the environment, which helps manufacturers to design products that meet specific environmental goals (Johansson \& Lindhqvist, 2005). At the design stage, the designer views the manufacturing through a closed loop that starts at design stage to product recovery management (Deif, 2011). All materials and energy requirements through the product life are considered. Green product design aims at reducing or eliminating hazardous material, minimizing waste in the product through the use of less material, designing products with recycling or re-use capabilities, and designing products for re-manufacturability and 
appropriate shapes and volume for minimal space consumption during storage and transportation (Khor \& Udin, 2013). Product sequencing is designed in a way to minimize motion which saves energy, cost, and time (Zhu \& Shang, 2008). Equipment and machine parameter controls are efficiently designed to minimize wastage through reworks and energy wastage. Raw materials considered for manufacturing of products by the designers should enhance sustainability by being less hazardous to the environment, minimize wastage of resources such as energy, and utilize green processes (Orji \& Wei, 2016).

Efficient processes are those processes that use green energy which minimizes wastage of resources with no rejects or rework required on products. The processes generate less undesirable wastes by minimizing production of solid wastes and reducing emission of green-house gases (Rashid, Sakundarini \& Thurasamy, 2017). The processes must have reliable and measurable standards that are defined by baseline quality controls (Chen, 2011). Efficient processes do not only meet but also exceed the quality conformance standards. Efficient processes also use minimum resources to create value addition in manufactured products that enhance competitive advantage (Elyateb, 2019). Green manufacturing technologies lead to substitution of raw materials with alternative raw materials, which are less hazardous, have re-manufacturing, as well as re-use and recycle capabilities (Varma, 2006; Ahn, 2014). The wastes are minimized through efficient use of resources by enhancing use intensity and any little wastes produced are consumed internally or recycled (Rosen \& Kishawy, 2012). Emission of gases and discharge of harmful wastes to the environment are highly controlled with the processes fitted with control filters (Ahmad, 2015). Resource reduction is enhanced by conservation of energy through batch optimization and proper product mix, with manufacturing firms adopting continuous processes (Rosen \& Kishawy, 2012; Rehman \& Shrivastava, 2013). Green processes enable firms to reduce material cost variance, improve on process efficiency and effectiveness, and reduce negative effects to the environment (Zhu \& Sarkis, 2007). This enables the firms to improve profit margins and grow market share. Employees should be empowered so as to incorporate total quality management principles in the production processes (Rao \& Holt, 2005). Use of safety systems and prevention measures are adhered to during production to prevent risks, damage, and accidents (Shi et al., 2012).

In addition, the relationship between green supply chain management (GSCM) and green manufacturing has significant implications to operational performance of the organization and environmental sustainability (Eltayeb, 2019). Collaboration between manufacturers and suppliers is essential to ensure that manufacturers supply raw materials, which are less hazardous and meet the required safety and health standards (Rao \& Holt, 2005; Sroufe, 2005). Compliance of suppliers to regulations and policies, eco-labelling and 
disclosure of products by use of environmental management system (EMS), reduces negative impacts to the environment by eliminating hazardous materials at the source (Eltayeb, 2019; Rao \& Holt, 2005). GSCM involves green warehousing where inventory levels are maintained at optimum levels with the objective of reducing inventory cost and usage of space (Eltayeb, 2019). Green packaging involves packaging products at reduced package materials. It also involves materials that can be recycled/re-used or materials that are harmless to human or animal life (Shi et al., 2012). Appropriate storage and apt disposal of hazardous materials eliminates waste, and negative effects to the environment are also considered a dimension of GSCM (Rashid et al., 2017). Greening SCM is positively associated with competitiveness since it leads to reduction of costs due to elimination of waste. Consequently, this provides customers with the same value at a reduced cost (Cosimato \& Troisi, 2015). Customer collaborations are an essential factor in GSCM since they ensure that customer needs are met effectively and their voice will be hard wired into the products (Vijayvargy, Thakkar \& Agarwal, 2017; Bai \& Sarkis, 2010).

End-of-life management aims at sustaining long-term ecological balance through recycling, re-use, and remanufacturing. Therefore, natural resources are safeguarded from depletion while ensuring that the environment is not harmed by disposal of materials (Eltayeb, 2019). Recycling, re-use, and remanufacturing must be factored in during product design and development through designing products for the environment. Thus, the organization should have a clear plan whereby components or materials should be recovered for remanufacturing or recycling at end of product life (Deif, 2011). Recycling is the most common recovery management method because it generates economic value for materials recovered through restoration of the functional capability that allows re-use. Therefore, the continuous use of new raw materials decreases which leads to improved sustainability (Maruthia \& Rashmi, 2015; Alvi, 2013). The manufacturer must maintain contact with the customer for purposes of collection of the product after end-of-life for either proper disposal, for remanufacturing or replacement during the warranty period. This has an advantage to the manufacturer because the changes in the needs of the customer can be easily identified, resulting in competitive advantage (Rao \& Holt, 2005). End-of-life management also helps in reducing cost through reduction in the consumption of virgin raw materials and reduction in material supply risk. Thus, natural resources are conserved and negative impacts to the environment are reduced tremendously (Khor \& Urdin, 2013). 


\section{Operational Performance}

Operational performance is the strategic dimension by which a company focuses to compete in (Narasimhan \& Das, 2001). These dimensions are cost, quality, flexibility, and speed (Ketchen, Rebarick, Hult \& Meyer, 2008). Therefore, manufacturing capabilities must be directed towards enhancing competitive priorities, thereby allowing the business unit to translate these dimensions to strategic capabilities. Operational performance seeks to reduce costs, achieve step-changes in productivity, and ensure that the customers are satisfied, leading to an improvement in organization profits. Operational performance further seeks to reduce operational cost and improve asset utilization through better maintenance, operating practices, and debottlenecking (Sawhney, 2006). Firm's competitive advantage depends on the ability to manipulate the four dimensions over their competitors. To reduce production costs, the manufacturers employ strategies that use energy efficiently, reduce inventory levels to optimal levels, employ processes that are efficient, reduce transportation costs due to proper location of warehouses and optimal product designs, and eliminate wastage of resources (Famiyeh et al., 2018; Orji \&Wei, 2016).

More so, the quality of product can be perceived as conformance of products to specifications. Therefore, performance measures ought to focus on eradicating non-conformance (Chen, 2011) so as to reduce costs and wastes incurred in rework and re-engineering. Poor quality leads to low stakeholder satisfaction, products failing in the market, and damage to the firm's image (Zhu, Sarkis \& Geng, 2005). Quality of products and processes can be achieved through quality management systems, green culture, and continuous improvement (Famiyeh et al., 2018).

Dynamism in customer needs has a significant impact on the manufacturing operations. This is because they should be customized towards meeting the needs of the customers, enabling the firm to remain competitive. There is increased environmental awareness to enhance sustainability. Hence, governments and organizations have set up policies and regulations (Kazancoglu et al., 2018) which are changed overtime (Alvi, 2013). Manufacturing strategies should be flexible in order to keep up with the changes in the external and internal environment. To deal with the changes, manufacturing firms adopt green manufacturing. Speed is the measure of how a company responds to customer needs in a timely manner in accordance with planned prices and costs (Ketchen et al., 2008). Therefore, manufacturing firms should optimize the product mix and batch size through the use of continuous production processes (Digalwar et al., 2016). Reducing time to market teamwork and collaborations is necessary in order to meet the needs of customers effectively, which in turn positively influences competitive advantage (Chase, Jacobs \& Acquillano, 2011). 


\section{Empirical Review}

A study by Shrivastava and Shrivastava (2016) opined that by adopting green production processes coupled with efficient use of energy, Indian cement manufacturers were able to cut cost and reduce negative effects of production to the environment without losing quality, reliability, and performance. Also, according to a study carried out by Fore and Mbohwa (2014), most of the South African Cement manufacturers used archaic methods. It was necessary for the industries to invest in process optimization and process control innovations in order to minimize waste and reduce the environmental impact on lime production. The manufacturing industries that adopted green methods such as bucket transport minimized the spillage and this led to reduction in waste of the raw materials and reduced emissions to the environment. They suggested that good housekeeping practices such as maintaining optimal inventories leads to reduction in production costs.

A study by Eshikumo (2017) opined that green manufacturing practices such as waste reduction and use of energy efficient processes has an effect of reducing cost of the production in cement manufacturing and thus enhancing operational performance. From the study, the firms that adopted green manufacturing practices minimize cost while preventing environmental pollution. They suggested that in Kenya, there was a need to enforce laws and regulations on environmental pollution since most of the industries had not adhered to the laws and regulations laid down. The study further revealed that green manufacturing practices are positively related to reduction of cost, which results from reduction of waste. A study by Orji and Wei (2016) established that the overall production cost of green manufacturing firms is much less than that in conventional manufacturing firms.

A study by Li and Zhang (2018) also revealed that green manufacturing positively impacts the environment due to reduction in waste, gases emission, and use of virgin materials. Another study by Digalwar et al. (2017) postulates that effective implementation of green manufacturing improves quality and reduces production cost. Furthermore, a study by Sezen (2011) suggested that eco-innovative processes enhance sustainability performance since green manufacturing lowers material cost and reduces production inefficiencies. Rao and Holt (2005) established that a strong positive association exists between green practices and environmental performance. This is in coherence with findings of a research carried out by Zhu and Sarkis (2005).

\section{Methodology}

\section{Research Design and Population}

The research design for the study was cross-sectional survey design with mixed elements of qualitative and quantitative approaches. Cross- 
sectional study was suitable since data was collected across several firms at one point in time (Cooper \& Schindler, 2006). The research design has been used in several studies (Rao \& Holt, 2015; Shrivastava \& Shrivastava, 2016; Deif, 2011; Digalwar et al., 2017). The target population of the study was 61 manufacturing firms registered by KAM as at $31^{\text {st }}$ December 2019 which were located within Mombasa County (KAM, 2019).

\section{Data Collection and Analysis}

Data was obtained via a matrix structured questionnaire. In designing the questionnaire, a five-point Likert scale with items ranging from ' $1=$ not at all' to ' 5 = very great extent ' were selected. Data was collected from operational managers because they are regarded as key informants with knowledge about the research topic (Kim et al., 2011; Purdie \& Hattie, 2003). A total of 61 questionnaires were issued using the drop-and-pick method. Multiple regression and correlation analysis were used for the study. Multiple regression was used to establish the relationship between the variables. The multiple regression model used to guide data analysis is as follows:

$Y=\beta_{0}+\beta_{1} X_{1}+\beta_{2} X_{2}+\beta_{3} X_{3}+\beta_{4} X_{4}+\varepsilon$ Equation 1

Where $\mathrm{Y}$ is the dependent variable, which is operational performance of manufacturing firms. $\beta_{0}$ is the $\mathrm{Y}$ intercept, which is the other factor affecting operational performance. $\beta_{1}, \beta_{2}, \beta_{3}$, and $\beta_{4}$ are the coefficients of the predictor variable. $X_{1}$ is green product design and development; $X_{2}$ is efficient processes; $\mathrm{X}_{3}$ is GSCM; $\mathrm{X}_{4}$ is end-of-life management, and $\varepsilon$ is the error term. Descriptive statistics was used to analyze data collected on general information of the manufacturing firms and the variables.

Correlation analysis was used to test for the relationship between the independent variable and the dependent variables. Coefficient of correlation and p-values were calculated and multi-collinearity was checked against the sub variables of the independent variable to test for the absence of correlation amongst the variables. Normality tests were determined by use of the ShapiroWilk test. Cronbach's Alpha was used to verify the reliability of each construct and items used in the study. The face validity of the questionnaires was enhanced by administering the questionnaires to five managers in the operational department. Thereafter, they were adjusted to cater for the raised issues. Content validity was ensured in the data collection tool through consultation with experts from literature (Hair, Money, Samuel \& Page, 2007).

\section{Findings and Discussion}

\section{Response Rate}

Out of the 61 questionnaires distributed, only 45 firms responded. The response rate was $73.77 \%$. Some firms did not respond because they had no 
survey policy, while others were due to flat refusal of respondents to respond to the questionnaire. The firms were distributed across all the sectors: Food, Beverage and Tobacco had majority of respondents (29.2\%), Plastics and Rubber (13.3\%), Chemical \& Allied (11.1\%), Textile and Apparels (8.9\%), Motor Vehicles \& Accessories (8.9\%). Building, Construction \& Mining, Metal \& Allied, and Electrical \& Electronics both constituted $6.7 \%$ of the respondents. Also, $4.4 \%$ of the industries surveyed dealt with Paper \& Board while Pharmaceuticals \& Medical and Consultancy \& Industrial Services had $2.2 \%$ each.

\section{Reliability Tests and Normality Tests}

Exploratory factor analysis (EFA) was done using principal component analysis with Varimax rotation. Before assessing the factor loadings, Kaiser-Meyer-Olkin Measures of sampling adequacy were evaluated to check the factorability of the items. For every EFA, it was found that manifest variables had KMO Measures of Sampling Adequacy above 0.665 as presented in Table 1. The value of KMO was above the threshold of 0.6 (Kaiser, 1974).

Table 1. KMO and Bartlett's Test

\begin{tabular}{|c|c|r|}
\hline \multicolumn{2}{|c|}{ Kaiser-Meyer-Olkin Measure of Sampling Adequacy } & .665 \\
\hline Bartlett's Test of Sphericity & Approx. Chi-Square & 42.068 \\
\cline { 2 - 3 } & Df & 6 \\
\cline { 2 - 3 } & Sig. & .000 \\
\hline
\end{tabular}

Table 2 represents Cronbach's Alpha, which was 0.633 at 5\% significance level indicating that the constructs were reliable since it surpasses the threshold of 0.6 (Hatcher,1994).

Table 2. Reliability Statistics

\begin{tabular}{|c|c|c|}
\hline Cronbach's Alpha & $\begin{array}{c}\text { Cronbach's Alpha Based } \\
\text { on Standardized Items }\end{array}$ & Number of Items \\
\hline .633 & .649 & 4 \\
\hline
\end{tabular}

The factor loadings for the constructs ranges from 0.594 to 0.82 as illustrated in Table 3, which is above the 0.3 threshold required that confirms high reliability. Green product design and development had a factor loading of 0.698, efficient processes had a factor loading of 0.82, GSCM had factor loadings of 0.741 , and efficient processes had factor loading of 0.594 . 
Table 3. Factor Loadings

\begin{tabular}{|l|c|c|c|}
\hline Variable & $\begin{array}{c}\text { Cronbach's } \\
\text { Alpha }\end{array}$ & $\begin{array}{c}\text { Factor } \\
\text { loading }\end{array}$ & $\begin{array}{c}\text { Item total- } \\
\text { correlation }\end{array}$ \\
\hline Green product design and development & 0.849 & 0.698 & 0.622 \\
\hline Efficient processes & 0.609 & 0.82 & 0.720 \\
\hline GSCM & 0.645 & 0.741 & 0.712 \\
\hline End-of-life product management & 0.602 & 0.594 & 0.544 \\
\hline
\end{tabular}

The test for normality was done through the use of Shapiro-Wilk and the results are presented in Table 4 . Green product design had p-value of 0.280 , efficient process had p-value 0.561 , GSCM had p-value of 0.060 , and end-of-life product management had p-value of 0.360. All the p-values were found to be more than 0.05 which implies normal distribution.

Table 4. Normality Tests

\begin{tabular}{|l|c|c|c|c|c|c|}
\hline & \multicolumn{3}{|c|}{ Kolmogorov-Smirnov $^{\mathrm{a}}$} & \multicolumn{3}{c|}{ Shapiro-Wilk } \\
\cline { 2 - 7 } & Statistic & Df & Sig. & Statistic & df & Sig. \\
\hline $\begin{array}{l}\text { Green product design } \\
\text { and development }\end{array}$ & .133 & 45 & .045 & .943 & 45 & .280 \\
\hline Efficient processes & .089 & 45 & $.200^{*}$ & .979 & 45 & .561 \\
\hline $\begin{array}{l}\text { Green supply chain } \\
\text { management } \\
\text { manufacturing in }\end{array}$ & .178 & 45 & .001 & .922 & 45 & .060 \\
\hline $\begin{array}{l}\text { End-of-life product } \\
\text { management }\end{array}$ & .117 & 45 & .138 & .973 & 45 & .360 \\
\hline
\end{tabular}

\section{Descriptive Analysis \\ Green Manufacturing}

Green manufacturing had four variables, namely: green product design and development, efficient processes, GSCM, and end-of-life product management.

Design of products and processes for environmental sustainability was to great extent $(\mathrm{Mean}=4.0222, \mathrm{SD}=0.98832)$. Product and process design for recycling was to moderate extent (Mean=3.3311, $\mathrm{SD}=1.14460)$, design of products for remanufacturing was to moderate extent (Mean=3.0444, $\mathrm{SD}=1.10691$ ), and design for reduction of material consumption was to great extent (Mean=3.8444, $\mathrm{SD}=0.97597)$. Reduction of energy consumption was to great extent $(\mathrm{Mean}=3.933, \mathrm{SD}=1.13618)$, reduction consumption of nonrenewable resources was to moderate extent (Mean=3.3778, $\mathrm{SD}=1.13396)$, and design for storage and transportation was to great extent (Mean=3.5111, $\mathrm{SD}=1.19891$ ). The grand mean for green product design and development was 3.5775 , indicating that the surveyed firms practiced green product design and development to great extent. 
Table 5. Green Product Design and Development

\begin{tabular}{|c|c|c|}
\hline & Mean & $\begin{array}{c}\text { Std. } \\
\text { Deviatio } \\
\mathrm{n}\end{array}$ \\
\hline Design of processes and product for environmental sustainability & 4.0222 & .98832 \\
\hline Design for recycling & 3.3111 & 1.14460 \\
\hline Design products for remanufacture & 3.0444 & 1.10691 \\
\hline Design products for material reduction & 3.8444 & 0.97597 \\
\hline Design products for renewable energy & 3.9333 & 1.13618 \\
\hline Design products and processes that saves energy & 3.3778 & 1.13396 \\
\hline Designing products for transportability & 3.5111 & 1.19891 \\
\hline
\end{tabular}

Reduction of virgin material consumption was to great extent (mean= 3.8667, $\mathrm{SD}=0.91949$ ) and reduction in energy wastage through efficient process was to great extent (mean=3.5556, $\mathrm{SD}=0.89330$ ). Reduction of consumption of non-renewable energy was to moderate extent (mean $=3.2444$, $\mathrm{SD}=1.11101)$. Elimination of hazardous and toxic materials in processes was to great extent (mean=4.0022, $\mathrm{SD}=1.23378$ ). Reduction of emission of harmful gases to the environment was to great extent (mean=3.7111, $\mathrm{SD}=0.86923)$. Recycling of internal waste was to a moderate extent (mean = 3.2889, $\mathrm{SD}=0.99138)$. Reduction of scrap and reworks was to great extent (mean $=4.0667, \mathrm{SD}=1.00905$ ). Reduction of energy consumption was to great extent (mean $=4.0222, \mathrm{SD}=0.89160)$. Reduction of material wastage was to a moderate extent (mean $=3.4000, \mathrm{SD}=1.00905)$. Therefore, the grand mean of 3.6884 implies that efficient processes amongst the manufacturing firms were to great extent.

Table 6. Efficient Processes

\begin{tabular}{|c|c|c|}
\hline Efficient Processes & Mean & $\begin{array}{c}\text { Std. } \\
\text { Deviation }\end{array}$ \\
\hline Recycling/ reusing materials for product manufacturing & 3.8667 & .91949 \\
\hline Energy saving processes & 3.5556 & .89330 \\
\hline Processes that use green energy & 3.2444 & 1.11101 \\
\hline Elimination of hazardous and toxic materials & 4.0222 & 1.23378 \\
\hline Control emission of harmful gases to the environment & 3.7111 & .86923 \\
\hline Recycling of internal waste generated & 3.2889 & .99138 \\
\hline Reduction in reworks and scrap & 4.0667 & 1.00905 \\
\hline Green culture & 4.0222 & .89160 \\
\hline Reduction in material wastage & 3.4000 & 1.00905 \\
\hline
\end{tabular}

Reduction in overall packaging of the products was to great extent (mean=4.2, $\mathrm{SD}=1.057)$. Purchasing raw materials from suppliers having environmentally friendly principles was to great extent (mean=4.00, $\mathrm{SD}=1.066)$. Transport modes with reduced energy were to great extent (mean=3.80, $\mathrm{SD}=1.1035$ ). Reduction of disposal of packaging materials was 
to great extent (mean=3.711, SD=0.895). Reduction in pollution by contracting firms that use environmentally friendly principles was to great extent (mean=3.5778, $\mathrm{SD}=0.8113$ ). Reduction on inventory levels was to great extent (mean=3.5111, $\mathrm{SD}=1.29021)$. Proper space utilization during storage and transportation was to moderate extent (mean $=3.4667, \mathrm{SD}=1.07872$ ). Delivery of products to the user site was to moderate extent (mean=3.3333 $\mathrm{SD}=1.10782$ ). Reduction in the use of non-biodegradable packaging material was to moderate extent (mean=3.0222, $\mathrm{SD}=1.252$ ). Therefore, the grand mean of 3.6247 implies that manufacturing firms were practicing GSCM to great extent.

Table 7. GSCM

\begin{tabular}{|c|c|c|}
\hline GSCM & Mean & $\begin{array}{c}\text { Std. } \\
\text { Deviatio } \\
\mathrm{n}\end{array}$ \\
\hline Reduction overall packaging of products & 4.2000 & 1.05744 \\
\hline $\begin{array}{c}\text { Purchasing raw materials from suppliers having environmentally } \\
\text { friendly principles }\end{array}$ & 4.0000 & 1.06600 \\
\hline $\begin{array}{c}\text { Transport modes with reduced energy wastage } \\
\text { Reduction of disposal of packaging material by using materials with } \\
\text { recyclable contents }\end{array}$ & 3.8000 & 1.01354 \\
\hline $\begin{array}{c}\text { Reduction in pollution by contracting firms that observe } \\
\text { environmentally friendly principles or EMS certified }\end{array}$ & 3.7111 & 0.89499 \\
\hline Reduction on inventory levels & 3.5111 & 1.29021 \\
\hline Proper space utilization during storage and transportation of the product & 3.4667 & 1.07872 \\
\hline Delivery of products directly to the user site & 3.3333 & 1.10782 \\
\hline Reduction use of non-biodegradable & 3.0222 & 1.25207 \\
\hline
\end{tabular}

Installation of collection points (mean $=3.6444, \mathrm{SD}=1.111)$ and safe disposal of non-recyclable waste (mean $=3.556, \mathrm{SD}=0.94281$ ) were practiced to great extent. Returning packaging material to suppliers (mean=3.400, $\mathrm{SD}=1.13618$ ), employing individual firms to collect waste generated (mean= $3.3778, \mathrm{SD}=1.07215$ ), provision of appropriate advice to customers (mean= 3.200, $\mathrm{SD}=0.99087$ ), and systems to monitor reverse logistics (mean $=3.0444$, $\mathrm{SD}=0.97597$ ) were practiced to moderate extent among the firms surveyed as represented in Table 8 . Cronbach's Alpha was 0.602 which confirms reliability and construct validity. A grand mean of 3.3704 was observed for end-of-life product management, implying that end-of-life product management among manufacturing was practiced to a moderate extent. 
Table 8. End-of-Life Product Management

\begin{tabular}{|c|c|c|}
\hline End-of-life product management & Mean & Std. Deviation \\
\hline $\begin{array}{c}\text { Installation of collection points for collection of used products and } \\
\text { packaging for reuse and recycling }\end{array}$ & 3.6444 & 1.11101 \\
\hline Safe disposal of non-recyclable waste (especially hazardous waste) & 3.5556 & .94281 \\
\hline $\begin{array}{c}\text { Used products and packaging are returned to suppliers for reuse or } \\
\text { recycling or remanufacturing }\end{array}$ & 3.4000 & 1.13618 \\
\hline $\begin{array}{c}\text { Employing individuals or firms to collect waste generated by our firm's } \\
\text { products. }\end{array}$ & 3.3778 & 1.07215 \\
\hline $\begin{array}{c}\text { Provision of appropriate advice to customers on the environmental } \\
\text { aspects of handling, use, and disposal of our firm's products }\end{array}$ & 3.2000 & .99087 \\
\hline Employing systems to monitor reverse flows of materials & 3.0444 & .97597 \\
\hline
\end{tabular}

Green product design and development was to great extent (Mean=3.5775), Efficient processes was to great extent (Mean=3.6884), GSCM was practiced to great extent (Mean=3.6247), and end-of-life product management was to moderate extent (Mean=3.3074). The results of the findings are represented in Table 9.

Table 9. Summary of Green Manufacturing Variables

\begin{tabular}{|l|c|c|}
\hline Variable & Mean & Standard deviation \\
\hline Green product design and development & 3.5775 & 1.0978 \\
\hline Efficient processes & 3.6884 & 0.9920 \\
\hline GSCM & 3.6247 & 1.0636 \\
\hline End-of-life product management & 3.3704 & 1.0382 \\
\hline
\end{tabular}

\section{Operational Performance}

Quality of the products (mean=4.2) improved by a great extent. This was made possible by the manufacturing firms adopting green manufacturing practices. Cost of operation (Mean=3.729) reduced by a great extent because of the adoption of green manufacturing practices. Speed in time to market $($ mean $=3.393$ ) greatly improved to a moderate extent because of the adoption of green manufacturing by the manufacturing firms. Flexibility in meeting customer demands (mean=3.207) by the manufacturing firms moderately improved because of the adoption of green manufacturing.

Table 9. Operational Performance Measures

\begin{tabular}{|c|c|c|}
\hline Operational performance measure & Mean & Std. Deviation \\
\hline Quality & 4.2 & 0.9972 \\
\hline Cost & 3.7926 & 1.1523 \\
\hline Flexibility & 3.207 & 1.1036 \\
\hline Speed & 3.393 & 1.1984 \\
\hline
\end{tabular}




\section{Coefficient of Determination}

Green product design and development had a value of $\mathrm{R}^{2}$ of 0.75 , implying that it can predict operational performance up to $75 \%$. Efficient processes had an $\mathrm{R}^{2}$ value of 0.77 , and this indicates that it can predict operational performance up to $77 \%$. GSCM had an $\mathrm{R}^{2}$ value of 0.59 , thus it could only predict operational performance up to 59\%. End-of-life product management is insignificant in predicting operational performance $\left(\mathrm{R}^{2}=-0.23\right.$, $\mathrm{p}=0.889>0.05)$. Therefore, the coefficient of determination was at $95 \%$ confidence level, and the results are shown in Table 10.

Table 10. Coefficient of Determination

\begin{tabular}{|c|c|c|c|c|c|}
\hline & $\begin{array}{c}\text { Type III } \\
\text { Sum of } \\
\text { Squares }\end{array}$ & $\begin{array}{c}\text { Mean } \\
\text { Square }\end{array}$ & $\mathrm{F}$ & $\begin{array}{c}\text { Adjusted } \\
\mathrm{R}^{2}\end{array}$ & Sig. \\
\hline $\begin{array}{c}\text { Green product design and } \\
\text { development }\end{array}$ & $33.625^{\mathrm{a}}$ & 33.625 & 4.571 & 0.75 & .038 \\
\hline Efficient Processes & $74.914^{\mathrm{b}}$ & 74.914 & 4.684 & 0.77 & .036 \\
\hline GSCM & $74.176^{\mathrm{c}}$ & 74.176 & 3.751 & 0.59 & .049 \\
\hline End-of-life product management & $.198^{\mathrm{d}}$ & .198 & .016 & -0.23 & .899 \\
\hline
\end{tabular}

\section{Regression Analysis}

The established regression equation shows that:

$\mathrm{Y}=5.352+0.140 \mathrm{X}_{1}+0.157 \mathrm{X}_{2}+0.135 \mathrm{X}_{3}-0.05 \mathrm{X}_{4}$ Equation 2

Where $\mathrm{Y}$ is the dependent variable, which is operational performance of manufacturing firms. 5.352 is the $\mathrm{Y}$ intercept, which is the other factor affecting operational performance. $X_{1}$ is green product design and development; $\mathrm{X}_{2}$ is efficient processes; $\mathrm{X}_{3}$ is GSCM; and $\mathrm{X}_{4}$ is end-of-life management. Green product design and development has a positive effect on operational performance (0.140). Efficient processes have a statistical significance on improvement of operational performance (0.157). GSCM has a statistical significance on improvement of operational performance (0.135), while end-of-life product management has a statistical insignificance effect which will lead to decrease in operational performance (-0.05). The VIF values of green design and development was 2.106, efficient processes had a VIF value of 1.906 , the VIF value of GSCM was 1.452, and end-of-life product management had a VIF value of 1.033. All the variables had VIF values of less than 5.0, indicating absence of multicollinearity (Ringle, Wende \& Becker, 2015). The results are presented in Table 11. 
Table 11. Coefficients

\begin{tabular}{|c|c|c|c|c|c|c|c|c|}
\hline \multirow{2}{*}{\multicolumn{2}{|c|}{ Model }} & \multicolumn{2}{|c|}{$\begin{array}{l}\text { Unstandardized } \\
\text { Coefficients }\end{array}$} & \multirow{2}{*}{$\begin{array}{c}\text { Standardized } \\
\text { Coefficients }\end{array}$} & \multirow[t]{2}{*}{$\mathrm{t}$} & \multirow[t]{2}{*}{ Sig. } & \multicolumn{2}{|c|}{$\begin{array}{l}\text { Collinearity } \\
\text { Statistics }\end{array}$} \\
\hline & & B & Std. Error & & & & Tolerance & VIF \\
\hline \multirow[t]{5}{*}{1} & (Constant) & 5.352 & 1.367 & & 3.915 & .001 & & \\
\hline & $\begin{array}{l}\text { Green product } \\
\text { design and } \\
\text { development }\end{array}$ & .292 & .446 & .140 & .656 & .002 & .475 & 2.106 \\
\hline & Efficient processes & .221 & .287 & .157 & .771 & .004 & .525 & 1.906 \\
\hline & $\begin{array}{c}\text { Green supply } \\
\text { chain management } \\
\text { in manufacturing }\end{array}$ & .173 & .228 & .135 & .759 & .004 & .689 & 1.452 \\
\hline & $\begin{array}{c}\text { End-of-life } \\
\text { product } \\
\text { management }\end{array}$ & -.086 & .255 & -.050 & -.336 & .739 & .968 & 1.033 \\
\hline
\end{tabular}

\section{Summary of the Model}

The summary of the model is presented in Table $12 . \quad \mathrm{R}$ at $95 \%$ confidence level was 0.363 , and this indicates that green manufacturing variables is associated with operational performance at 0.363 . The adjusted $\mathrm{R}^{2}$ is a coefficient of determination which predicts a variance of $4.5 \%$ at $95 \%$ confidence level between operational performance and green manufacturing variables. Thus, green manufacturing had positive relationship with operational performance and the standard error estimate was 5.74537.

Table 12. Summary of the Model

\begin{tabular}{|c|c|c|c|c|}
\hline Model & $\mathrm{R}$ & R Square & Adjusted R Square & Std. Error of the Estimate \\
\hline & $.363^{\mathrm{a}}$ & .132 & .045 & 5.74537 \\
\hline
\end{tabular}

$\boldsymbol{H}_{\boldsymbol{0}}$ is rejected and the alternative hypothesis $\boldsymbol{H}_{\boldsymbol{l}}$ is accepted.

\section{Analysis of Variance}

The independent variables have a total variance of 150.67064 , and this constitutes the variance of the operational performance. F-test value (2.518) is greater than the F-critical which is 1.562 at $95 \%$ confidence level. This indicates that the model green manufacturing variables were a good fit for the data. The strength of variation between green manufacturing and operational performance in the firms surveyed was significant $(\mathrm{p}=0.015<0.05)$

Table 13. ANOVA ${ }^{a}$

\begin{tabular}{|l|l|l|l|l|l|l|}
\hline \multicolumn{2}{|l|}{ Model } & Sum of Squares & Df & Mean Square & F & Sig. \\
\hline 1 & Regression & 30.31064 & 4 & 7.5766 & 2.518 & $.015^{\text {b }}$ \\
\cline { 2 - 7 } & Residual & 120.36 & 40 & 3.009 & & \\
\hline & Total & 150.67064 & 44 & & & \\
\hline
\end{tabular}

a. Dependent Variable: Operational Performance

b. Predictors: (Constant), End-of-life product management, Green supply chain management in manufacturing, Efficient Processes, Green product design and development. 


\section{Discussion of Findings}

Design for environmental sustainability, design for renewable energy sources, and design for material reduction were highly considered during the design stage by the surveyed firms. During the manufacturing stage, firms employ processes that use green energy, save energy, reduce toxic \& hazardous materials, reduce reworks, and scrap. In the supply chain, firms reduced the overall package materials and purchased supplies that were environmentally friendly. In the end-of-life management stage, firms had installed collection points to collect materials for recycling and employed individuals to collect materials. These considerations are as a result of shrinking supply of raw materials and pressure to use renewable sources of energy, which is aimed at reducing pollution. This propels the argument that green manufacturing is a continuous loop starting with the product design stage to the end-of-life product management.

Design for transportability is in tally with manufacturing firms employing transport means that are environmentally friendly/EMS certified. This aids delivery of products to site and proper utilization of storage space in the supply chain management. Employing transport modes that reduce energy and are environmentally friendly eliminates the negative effects to the environment. However, recycling was often practiced in manufacturing firms compared to remanufacturing.

The findings of the study showed that green manufacturing leads to enhanced operational performance. Production cost significantly reduced because of the adoption of green manufacturing. More so, the quality of the products significantly improved due to implementation of green manufacturing. Green manufacturing leads to quality improvement of products by ensuring that the products produced conform to specifications and do not fail in the market. Green manufacturing also leads to increased flexibility and speed. Furthermore, green manufacturing leads to improvement in delivery of products, reduction in time taken to market, and time taken to respond to changes in tastes. The findings revealed that green manufacturing has a positive significant relationship with operational performance.

Adoption of green manufacturing significantly improves quality, reduces cost, improves flexibility, and enhances speed. All of these have a cumulative effect of increasing the competitive advantage of the firm. Despite the efforts made to move from conventional manufacturing, firms still experience challenges such as high technological risks. This is because technology keeps on changing and high short-term costs leads to inadequate organizational resources, varying customer demands, and green organizational culture.

The study further established that the implementation of green manufacturing in totality leads to reduction in production cost, increased 
flexibility, increased speed, and improved quality. This enhances operational performance, which leads to the firm gaining competitive advantage. Implementing green manufacturing contributes to a wide range of competitive benefits and environmental sustainability. It leads to reduction in wastes produced. Nonetheless, those that are produced are recycled, while those that cannot be recycled are disposed of safely so as to reduce pollution. Reduction in the overall packaging was the most employed green manufacturing concept. This is followed by reduction in scrap and elimination of hazardous and toxic materials. Recycling and design for the environment were highly implemented among the manufacturing firms.

End-of-life product management was the least practiced green manufacturing concept among the manufacturing firms. To embrace the practice requires long-term investment and commitment by the firm, and most of the firms are lacking in this aspect. The low practice of end-of-life management is also attributed to inadequate government support or pressure from other institutions since most of the manufacturing firms surveyed were found to be operating locally. Manufacturing firms ought to install collection points to collect the used products for the purposes of recycling or remanufacturing. This reduces disposal of waste and enhances environmental and sustainability performance. Installation of collection points should be coupled with putting systems in place to monitor reverse flow of materials so as to enhance effectiveness and efficiency of the process.

\section{Conclusion}

The study showed that green product design and development was statistically significant to operational performance of manufacturing firms with the effect being positive. Green product design and development has an effect of eliminating toxic and hazardous materials, reducing time to market, and planning for the energy requirements and tools, which affects the other stages of production. Green product design and development enhances speed, improves flexibility, reduces cost of production, and ensures that products do not fail in the market, which positively affects competitive advantage of the firm.

The study also revealed that efficient processes have a positive relationship with operational performance of manufacturing firms. Efficient process reduces wastage of materials, eliminates rejects and reworks, enhances utilization of green energy, saves energy, and improves continuous production. This in turn reduces machine set-up time and moderates unnecessary motions and transportation through proper sequencing of the production process. Thus, this will lead to cost reduction and improved quality and speed so that the needs of customers are effectively met. 
The study established that GSCM has a positive effect on the operational performance of manufacturing firms. GSCM practices reduced storage cost by ensuring optimum inventory levels, eco-labelling of products, reduction in storage and transportation space, elimination of hazardous package materials, reduction in overall packaging, optimization of warehousing practices, and delivery of products to customers' site. GSCM practices lead to reduction in cost, hence positively influencing operational performance. The established end-of-life product management had a negative effect on operational performance of manufacturing firms. Most of the firms surveyed engaged in recycling and not remanufacturing. Also, most of the firms did not engage in collection of the products from their customers. This contributes to the effect of end-of-life product management having an insignificant effect on operational performance.

The study further revealed that green manufacturing has a positive relationship with operational performance. Manufacturing firms ought to implement green manufacturing practices in all the stages of manufacturing, which begins with product design and development, efficient processes, GSCM, and end-of-life product management since green manufacturing is a continuous loop. Manufacturing firms will gain competitive advantage when they implement green manufacturing since it leads to quality improvement, reduction in cost, increased flexibility, and speed

\section{Contributions of the Study}

Managers should commit to long-term investment on green product and process designs since it determines effectiveness of other stages in the loop of green manufacturing. This implies that they should invest more on research and development. The government and other regulating institutions should come up with policies that encourage manufacturing firms to implement end-of-life product management practices since it is the least practiced green manufacturing concept. This is attributed to the fact that it eliminates the need for disposal and additional consumption of virgin raw materials and enhances the firm's image to gain competitive advantage.

Government should thus re-evaluate the regulatory structure and policies that can facilitate end-of-life product management and recovery. The government and manufacturing firms should also engage in public awareness on the benefits of collection and recovery of used products and packaging among consumers. This is because recovery of products has a significant impact on reducing pollution.

The major contribution to knowledge of this study is that it has a sound theoretical foundation and prior empirical analysis that the implementation of green manufacturing has a positive direct effect on operational performance. Consequently, the finding adds to the body of knowledge on positive links 
between the effectiveness of green manufacturing and operational performance. This finding also helps to clear the air on the true effect of green manufacturing on operational performance. Furthermore, the research adds to the existing pool of knowledge on green manufacturing and operational performance by investigating the paths that enhance operational performance.

\section{Study Limitations and Suggestions for Further Study}

Despite the study providing valuable insights, it has some limitations. Firstly, the findings of the study were centered on cross-sectional data. In future research, the longitudinal research design could be used to enhance the reliability of performance data. Secondly, data was obtained from individual managers in operations departments. While it is anticipated that respondents will offer unbiased answers because of variations in their role and profession, they could have contributed to differing perceptions as to how items in questionnaires were addressed. Therefore, further studies are required to evaluate the impact from other departments such as finance and supply chain and also from the customer's perspective. This is because quality from the manufacturer's perspective is conformance to set standards. On the other hand, it is the perception of value addition from the customer's standpoint. Intervening variables such as management support and government policies on implementation of green manufacturing were assumed in the study. Thus, further research should be carried to determine their influence.

\section{References:}

1. Ahmad, S. (2015). Implementation of green manufacturing in reducing carbon contents in steel industry to improve air quality and business results. International Journal of Emerging Technology and Advanced Engineering, 5 (6), 1-6.

2. Ahn, S. H. (2014). An evaluation of green manufacturing technologies based on research databases, International Journal of Precision Engineering and Manufacturing-Green Technology, 1 (1), 5-9.

3. Alvi, S. (2013). Approaching green manufacturing in iron and steel industry. International Journal of Mechanical Engineering and Robotics Research, 2 (3.)

4. Bai, C. \& Sarkis, J. (2010). Green supplier development: Analytical evaluation using rough set theory. Journal of Cleaner Production, 18 (12), 1200-1210.

5. Bhattacharya, A. (2011). Green manufacturing - energy, products and processes. Proceedings of Confederation of Indian Industry. USA, Boston. 
6. Chase, R. B., Jacobs, F. R., \& Aquilano, N. J. (2011). Operations management for competitive advantage. (1 $1^{\text {th }}$ Ed.). Boston, Burr Ridge, Illinois, USA: McGraw-Hill Irwin.

7. Chen, S. (2011). Green organizational identity: sources and consequence. Management Decision, 49(3), 384-404

8. Cooper, D. R. \& Schindler, P. S. (2006). Business research methods. $\left(9^{\text {th }}\right.$ Ed.). Boston, USA: McGraw-Hill

9. Cosimato, S. \& Troisi, O. (2015). Green supply chain management: Practices and tools for logistics competitiveness and sustainability. The DHL case study, The TQM Journal, 27 (2), 256-276.

10. Deif, M. (2011). A system model for green manufacturing. Journal of Cleaner Production, 19 (14), 1553-1559.

11. Digalwar, A.K., Mundra, N., Tagalpallewar, R.A., \& Sunnapwar, V.K. (2017). Road map for the implementation of green manufacturing practices in Indian manufacturing industries: An ISM approach, Benchmarking: An International Journal, 24 (5), 1386-1399.

12. Drost, E. (2008). Validity and Reliability in Social Science Research, Education Research and Perspectives, 38 (1), 1-21.

13. Eltayeb, T.K. (2019). Green manufacturing initiatives among certified companies in Malaysia and environmental sustainability: Investigating the outcomes, Resources, Conservation and Recycling, 55 (5), 495506.

14. Eshikumo, S. (2017). Green Manufacturing and Operational Performance of a Firm: Case of Cement Manufacturing in Kenya. International Journal of Business and Social Science, 8(4).

15. Famiyeh, S., Adaku, E., Gyampha, K., Darko, D., \& Teye, C. (2018). Environmental management practices, operational performance and environmental performance. Journal of Manufacturing Technology Management, 29 (3), 588-607.

16. Fore, S. \& Mbohwa, C. (2015). Greening manufacturing practices in a continuous process industry: Case study of a cement manufacturing company. Journal of Engineering, Design and Technology, 13 (1), 94122.

17. GoK (2009). Kenya Population and Housing Census. Nairobi: Government Printers.

18. GoK (2019). Kenya Population and Housing Census. Nairobi: Government Printers.

19. Hair, J. F., Money, A. H., Samouel, P., \& Page, M. (2007). Research methods for business. West Sussex, England: John Wiley and Sons.

20. Hatcher, L. (1994). A step-by-step approach to using the $S A S(R)$ system for factor analysis and structural equation modeling. Cary, NC:

SAS Institute. 
21. Johansson, T.B. \& Lindhqvist, T. (2005). Management and policy for sustainable consumption and production, Journal of Cleaner Production, 13 (10), 967-979.

22. Joppe, M. (2000). The Research Process. Retrieved September 30, 2019 from http://www.ryerson.ca/ mjoppe/rp.htm.

23. Kaiser, H. F. (1974). An index of factorial simplicity. Psychometrika, 39 (1), 31-36.

24. KAM (2019). KAM Directory 2018/2019. Nairobi: Oxford Printing Press.

25. Kazancoglu, Y., Kazancoglu, I., \& Sagnak, M. (2018). Fuzzy MEDMATEL-based green supply chain management performance: an application in cement industry. Industrial Management and Data Systems, 118 (2), 412-431.

26. Ketchen, D. J., Rebarick, W., Hult, G. T. M., \& Meyer, D. (2008). Best value supply chains: A key competitive weapon for the 21 st century. Business Horizons, 51(3), 235-243.

27. Khor, K. \& Udin, M. (2013). Reverse logistics in Malaysia: Investigating the effect of green product design and resource commitment. Resources Conservation and Recycling Journal, 81(2), 78-81.

28. Kim, G., Shin, B., Kim, K. K., \& Lee, H. G. (2011). IT capabilities, process-oriented dynamic capabilities, and firm financial performance. Journal of the association for information systems, 12(7), 487-517.

29. Li, Y. \& Zhang, M. (2018). Green manufacturing and environmental productivity growth. Industrial Management \& Data Systems, 118 (6), 1303-1319.

30. Maruthia, G.D. \& Rashmi, R. (2015). Green manufacturing: its tools and techniques that can be Implemented in manufacturing sectors, Proceedings of 4th International Conference on Materials Processing and Characterization, 3350-3355.

31. Narasihman, R. \& Das, A. (2001). The impact of purchasing integration and practices on manufacturing performance, Journal of Operations management, 19 (5), 593-609.

32. NEEMA (2018). Environmental Pollution Report. Nairobi: Government Printers.

33. Orji, I. \& Wei, S. (2016). A detailed calculation model for costing of green manufacturing. Industrial Management and Data Systems, 116 (1), 65-86.

34. Purdie, F. \& Hattie, J. (2003). An evaluation of typologies of marketplace strategic actions, European Journal of Marketing, 37 (3/4), 498-529 
35. Rashid, S., Sakundarini, N., \& Thurasamy, R. (2016). The impact of sustainable manufacturing practices on sustainability performance: Empirical evidence from Malaysia. International Journal of Operations and Productions Management. 37 (2), 182- 204.

36. Rao, P. \& Holt, D. (2005). Do green supply chains lead to competitiveness and economic performance? International Journal of Operations \& Production Management, 25 (9), 898-916.

37. Rehman, M. \& Shrivastava, R. (2013). Green manufacturing; past, present and future. World review of science, technology and sustainable development. $10(1 / 2 / 3)$.

38. Ringle, C.M., Wende, S., \& Becker, J. M. (2015). SmartPLS 3, Scientific Research Journal 10 (1), 670-682.

39. Rosen, M. \& Kishawy, H. (2012). Sustainable manufacturing and design: Concepts, practices and needs, Sustainability, 4 (2), 154-174.

40. Rundh, B. (2013). Packaging design: creating competitive advantage with product packaging. British Food Journal, 111 (9), 988-1002.

41. Sarkis, J., Zhu, Q., \& Lai, K. H. (2011).An organizational theoretic review of green supply chain management literature. International Journal of Production Economics, 130 (1), 1-15.

42. Sarkis, J. (2012). A boundaries and flows perspective of green supply chain management. Supply Chain Management, 17 (2), 202-216.

43. Sawhney, R. (2006). Interplay between uncertainty and flexibility across the value chain: towards a transformation model of manufacturing flexibility. Journal of Operations Management 24 (5), 476-493.

44. Sezen, D. (2013). Effects of green manufacturing and eco-innovation on sustainability performance. Procedia - Social and Behavioral Sciences, 99 (2), $154-163$

45. Simpson, D., Power, D., and Samson, D. (2007). Greening the automotive supply chain: a relationship perspective. International Journal of Operations \& Production Management, 27 (1), 28-48.

46. Sivapirakasam, S. P., Mathew, J., \& Surianarayanan, M. (2011). Multiattribute decision making for green electrical discharge machining. Expert Systems with Applications, 38 (7), 8370-8374.

47. Shang, K., Lu, C. S., \& Li, S. (2010). A taxonomy of green supply chain management capability among electronics-related manufacturing firms in Taiwan. Journal of Environmental Management, 91(5), 1218-1226.

48. Shi, V.G., Koh, L.C., Baldwin, J., \& Gucchiella, F. (2012). Natural resource based green supply chain management, Supply Chain Management: An International Journal, 17 (1), 54-67. 
49. Shrivastava, S. \& Shrivastava, L. (2017). A systematic literature review on green manufacturing concepts in cement industries. International Journal of Quality \& Reliability Management, 34 (1), 68-90.

50. Szafran, R.F. (2012). Answering Questions with Statistics, $\left(1^{\text {st }}\right.$ Ed.) .USA, California: Sage Publishers, Inc.

51. Trochim, W. M. K. (2006). The Qualitative Debate. Research Methods Knowledge Base. Creative Education, 7 (4).

52. Waithaka, S., Mburu, T., Koror, J., \& Muathe, S. (2013). Environmental Factors that influence Supply Chain Management Implementation in then Manufacturing Industries in Kenya: A Case of Manufacturing Industries in Nairobi, Kenya. ABC Journal of Advanced of Research, 1(2), 42-47.

53. Varma, S. (2006). Implementing supply chain management in a firm: issues and remedies. Asia Pacific Journal of Marketing and Logistics, 18 (3), 223-243.

54. Vijayvargy, L., Thakkar, J., \& Agarwal, G. (2017). Green supply chain management practices and performance: The role of firm size for emerging economies. Journal of Manufacturing Technology Management, 28(3), 299-323.

55. UNICEF (2017). Kenya Humanitarian Situation Report.

56. Zhang, M. (2018). Green Manufacturing and Environment Productivity Growth on European Manufacturing Firms. International Journal of Production Economics, 130 (1), 1-15.

57. Zhu, Q., Sarkis, J., \& Geng, Y. (2005). Green supply chain management in China: pressures, practices and performance. International Journal of Operations \& Production Management, 25(5), 449-468. 